\title{
日本語における借用語のアクセント \\ 一中国語借用語の韻律現象と最適性理論一 \\ On Loanword Accentuation in Japanese: \\ Accent patterns of adapted forms from Chinese and Optimality Theory
}

菊島 和紀

淡江大学

\section{要旨}

本研究は、日本語における中国語借用語の韻律現象、特に名詞の語アクセントの 特徵について、最適性理論 (Optimality Theory) を用いて考察を試みた。まず、日本 人にとって馴染みのある中国語の料理名および中国の地名から異なる音節構造を 持つものを選び、日本語への借用語となるよう音節量を変化させたものが標準語と してどのようなアクセント構造となるかを観察した。英語の借用語と同様、中国語の 場合もその多くが語末から 3 番目の音節に強勢が置かれるが (Antepenultimate Rule: McCawley 1968)、それに加え、本論文では最適性理論から 7 つの制約 (constraint)を 取り上げて、その優先順位を次のように示した: NONFINALITY, FT-BIN, RHTYPE=T, ALIGN-FT-L 》ALL-FT-R》WSP, PARSE- $\mu$ 。また、軽音節十軽音節十重音節、重 音節十軽音節十重音節の 2 種の異なる構造を持つ場合はインフォーマントによって アクセントの位置に違いが見られるが、世代間の差異と言われるこのアクセントの 問題を、制約の一つである音節非末端性を用いてその最適性を論じた。

キーワード : Optimality Theory, loanword, constraint, antepenultimate rule 
On Loanword Accentuation in Japanese:

Accent patterns of adapted forms from Chinese and Optimality Theory

菊島 和紀

淡江大学

\section{Introduction}

This paper analyzes loanword accentuation in Japanese, with a focus on the accent patterns of adapted forms from Mandarin Chinese. In Japanese, content words fall into two accent classes: "accented" and "unaccented." Accented words involve an abrupt pitch fall, whereas their unaccented counterparts are pronounced with a rather flat pitch, even when they are followed by a particle like the nominative particle /ga/. Some typical examples are given in (1) for each of the three types of lexical words: native, Sino-Japanese, and loanwords. The dots indicate syllable boundaries, and the pitch falls in accented words are represented with a diacritic.

(1) a. Accented nouns

(native) í.no.ti "life," ko.kó.ro "heart," o.to.kó "man"

(Sino-Japanese) ká.ga.ku "science," kyóo.to "Kyoto," ga.kú.mon "study" (loanwords) rón.don "London," oo.su.to.rá.ri.a "Australia"

b. Unaccented nouns

(native) mu.shi "insect," ne.zu.mi "mouse"
(Sino-Japanese) ga.ku.see "student," too.kyoo "Tokyo"
(loanwords) a.me.ri.ka "America," su.te.re.o "stereo," in.fu.re "inflation"

For many Japanese lexical items, the accent is lexical, while the accent is assigned by default for others. In foreign word adaptation, we observe default accent patterns because input words do not always contain an accent specification. This default accentuation seems to be applied to the forms adapted from Chinese. For example, in the adapted word /syanhai/ "Shanghai", the accent is placed on the syllable that contains the third mora from the end of the word. It seems that the accentuation of loanwords from Chinese also follows the default "antepenultimate accent rule," which will be discussed below.

In this paper, I analyze loanword accentuation, specifically focusing on the accent patterns of adapted forms from Mandarin Chinese. In addition, I discuss similarities and differences between loanwords from English and those from Chinese in terms of accent patterns. This paper is organized as follows: Section 2 is a descriptive presentation of the 
accentuation of loanwords from English, which is based on the analysis by Kubozono (1999a, 1999b, 2001, 2006). In Section 3, data of adapted forms from Mandarin Chinese are offered and their default accent patterns are analyzed under the Optimality Theory (OT) framework. In addition, Section 3 also addresses some problematic data that cannot be explained using the default rule. Section 4 is the conclusion.

\section{Accentuation of accented loanwords}

In this section, I present some characteristics of loanword accentuation based on the work of Kubozono (1999a, 1999b, 2001, 2006), who offers extensive observations on the subject. A summary explanation of the characteristics of loanword accentuation is provided below.

\subsection{Default accent patterns of loanwords from English}

Tokyo Japanese is a typical mora language, as opposed to a syllable language. Accent rules are no exception in this regard and can be formulated by invoking the mora as a basic descriptive unit. Most loanwords are known to follow the "antepenultimate rule" demonstrated in (2), if they are lexically accented (McCawley, 1968). This is exemplified in (3).

(2) Loanword accent rule (antepenultimate rule)

Add an accent on the syllable containing the antepenultimate mora, or the third mora from the end of the word.

(3) a. Three-mora loanwords

pú.ra.su "plus," páa.ku "park," pú.ri.n "pudding," rí.ree "relay"

b. Four-mora loanwords su.tó.re.su "stress," bi.tá.min “vitamin," rón.don "London"

c. Five-mora or longer loanwords ku.ri.sú.ma.su "Christmas," wa.sín.ton "Washington,” yoo.róp.pa "Europe”

Non-syllabic moras such as a moraic nasal, a moraic obstruent, the second-half of long vowels and the second-half of diphthongal vowel sequences serve as independent timing units just like CV moras that constitute a syllable by themselves. Thus, the accent pattern of loanwords listed in (3) can be explained by the antepenultimate rule defined in (2). 


\subsection{Loanword accent and vowel epenthesis}

As Kubozono (2006) points out, trimoraic loanwords clearly prefer an initial accent irrespective of their syllable structure. This is in full accordance with the traditional "antepenultimate rule" defined in (2). In this case, epenthetic vowels do not seem to resist bearing an accent in word-initial position, as exemplified in (4), where epenthetic vowels are enclosed in $<$.

$\mathrm{p}<$ ú>.ra.s $<\mathrm{u}>$ "plus," $\mathrm{t}<$ ó $>$.ri.o "trio"

While the antepenultimate accent is preferred, some of $\operatorname{light}(\mathrm{L})+$ heavy $(\mathrm{H})$ bisyllables permit an accent on the final syllable, as shown in (5).

$\mathrm{p}<\mathrm{u}>$.rée "play," $\mathbf{s}<\mathrm{u}>$.rée "three," $\mathbf{s}<\mathrm{u}>$.kái “sky"

(6) pú.rin "pudding," ríree "relay"

Although LH bisyllables generally follow the antepenultimate pattern as in (6), they take an accent on the final heavy syllable if the initial light syllable contains an epenthetic vowel. Kubozono (2006) explains that this accent displacement should be attributed to the combination of two factors: no accent on epenthetic vowels and the weight-to-stress principle (WSP).

\subsection{Pre-antepenultimate patterns in loanword accent}

When the antepenultimate rule in (2) is reinterpreted in terms of the syllable, an accent is placed on the second or third syllable from the end of the word. Depending on the weight of the last three syllables, words can be categorized into eight groups: HHH\#, HHL\#, LHH\#, LHL\#, HLH\#, HLL\#, LLH\#, and LLL\#. Although most loanwords follow the antepenultimate rule, loanwords with HLH\# and LLH\# structures tend to be accented on the antepenultimate syllable rather than on the penultimate light syllable. That is, the accent patterns of loanwords with HLH\# and LLH\# cannot be explained by the antepenultimate rule defined in (2). Consider the examples in (7) and (8).

(7) a. tó.ro.fii "trophy," té.ne.sii "Tennessee"

b. máa.ga.rin "margarine," páa.to.naa "partner," bu.rók.ko.rii "broccoli”

(8) a. e.ne.rú.gii / e.né.ru.gii "energy," do.rá.gon / dó.ra.gon "dragon"

b. han.gá.rii / hán.ga.rii "Hungary," a.koo.dí.on / a.kóo.di.on "accordion" 
When the accent is placed on the syllable containing the pre-antepenultimate mora, or the fourth mora from the end of the word, as in (7) and (8), the accentuation is referred to as "pre-antepenultimate pattern."

\subsection{Unaccented words}

Analyzing about 700 foreign place names used in Japanese as a source of data, Kubozono (1999b) argues that four-mora loanwords tend to be unaccented when they end in a sequence of light syllables, as shown in (9).

(9) a.me.ri.ka "America," $\mathbf{s}<\mathrm{u}>$.te.re.o "stereo," in.h<u>.re "inflation," a.ri.zo.na "Arizona," ho.no.ru.ru "Honolulu"

Further, Kubozono (1999b) suggests that the unaccented pattern is particularly popular if the word-final light syllable does not contain an epenthetic vowel. For example, the English words "stress" and "trouble" are borrowed as accented words $\mathrm{s}<\mathrm{u}>\mathrm{t}<\mathrm{o}>$.re.s $<\mathrm{u}>$ and $\mathrm{t}<\mathrm{o}>$.rá. $\mathrm{b}<\mathrm{u}>\mathrm{r}<\mathrm{u}>$, respectively. However, the unaccented four-mora loanwords do not involve non-epenthetic vowel in the word-final position, as in (9).

\section{Accent patterns of adapted forms from Mandarin Chinese}

\subsection{Data for analysis}

In this section we consider the accent structure of adapted forms from Mandarin Chinese. The analyzed data were collected from Japanese speakers residing in Tokyo ${ }^{1}$. Because Japanese native speakers who understand Mandarin Chinese tend to experience difficulties in specifying the place of the accent, I elected informants who do not have any knowledge or information on Mandarin Chinese at all. To clarify the accent position, I asked them to read naturally Chinese words that were transcribed in the katakana writing system by the author. For the analysis, I selected 58 nouns (names of places in Mainland China and names of Chinese foods) $)^{2}$.

17 Japanese native speakers residing in Tokyo were invited as informants. The details of their genders and age groups are as follows: two females and one male in 20 s, one female and one male in 30 s, one female in $40 \mathrm{~s}$, and one male in 50s.

2 Regarding the selection of nouns, I referred to Akegi (2014) for names of places in Mainland China and Fukutomi (2011) for names of Chinese foods. The nouns that I chose at random from them were classified by the number of mora, and their syllable structures were also considered to narrow down the list. 
Consider the examples in (10) to (12).

(10) Two-mora nouns

$$
\text { \#LL\# rá.sa “Lasa” (拉薩) }
$$

(11) Three-mora nouns

$$
\begin{array}{ll}
\text { \#HL\# } & \text { sán.ya “Sanya” (三亞) } \\
\text { \#LH\# } & \text { jyú.hai “Zhuhai” (珠海) } \\
\text { \#LLL\# } & \text { jyá.mu.su “Jiamusi” (佳木斯) }
\end{array}
$$

(12) Four-mora nouns

$$
\begin{array}{ll}
\text { \#LLLL\# } & \text { u.ru.mu.ti “Ulumuqi” (烏魯木齊), ti.ti.ha.ru “Qiqihaer” (齊齊哈爾) } \\
\text { \#HLL\# } & \text { an.ho.e “Anhui”(安徽), puu.a.ru “puer”(普洱) } \\
\text { \#LHL\# } & \text { ti.tái.ho “Qitaihhe”(七台河) } \\
\text { \#LLH\# } & \text { sí.a.men / si.á.men “Xiamen”(廈門) } \\
\text { \#HH\# } & \text { syán.hai “Shanghai”(上海), úu.han “Wuhan”(武漢) }
\end{array}
$$

As shown in the examples listed above, adapted forms of Chinese words are accented by the informants in the following ways: (i) in bimoraic nouns that consists of two light syllables, the accent is placed on initial syllable invariably, as in (10); (ii) trimoraic words clearly prefer an initial accent irrespective of their syllable structure, as in (11); (iii) as for four-mora nouns that consist of four light syllables (LLLL\#) or in which an initial heavy syllable is followed by two light syllables (HLL\#), an unaccented pattern is observed; (iv) for four-mora words that involve a sequence of LHL\# or HH\#, their accentuation follows the antepenultimate rule discussed in 2.1; (v) for the four-mora nouns which involve two light syllables followed by a heavy syllable (LLH\#), we can observe two variations: accent placement on the first or the second light syllable.

The next question is whether or not it is possible that the antepenultimate rule accounts for the accent patterns of five-mora or longer nouns. When the antepenultimate rule is reinterpreted in terms of the syllable, an accent is placed on the second or third syllable from the end of the word. Consider the examples in (13). 
(13) Combinations of heavy and light syllables in the word-final position
a. HHH\# maa.án.syan “Ma’anshan” (馬鞍山), ban.bán.jii “bangbangji” (棒棒雞), too.bán.jyan “doubanjiang” (豆瓣醬)
b. HHL\# maa.boo.dóo.fu “mapodoufu” (麻婆豆腐)
c. LHH\# ti.én.jin “Tianjin” (天津), gon.ba.o.jíi.din “gongbaojiding” (宮保雞丁), ho.i.góo.roo "huiguorou” (回鍋肉)
d. LHL\# ji.én.ri “Jianli” (監利)
e. HLH\# dáa.ri.en “Dalian” (大連)， rón.i.en / ron.í.en “Longyan” (龍岩)
f. HLL\# tín.ta.o “Qingdao” (青島)
g. LLH\# gaa.á.ru.muu “Ge’ermu” (格尔木), tó.ru.fan“Tulufan” (吐魯番), yú.e.bin “yuebing” (月餅)

h. LLL\# puu.á.ru.tya “puercha” (普洱茶), moo.rii.hú.a.tya “molihuacha” (茉莉 花茶)

Most of the adapted words from Chinese listed above follow the antepenultimate rule in (2). However, words with HLH\# and LLH\# structures tend to be accented on the antepenultimate syllable rather than on the penultimate light syllable. That is, the accent patterns observed here is the same as those of loanwords, as discussed in section 2 . The accent is placed on the syllable containing the pre-antepenultimate mora, or the fourth mora from the end of the word in (13e) and (13g), i.e. 'pre-antepenultimate pattern'.

\subsection{Foot binarity}

The notion of the bimoraic foot plays a crucial role in word accent phenomena in Japanese. The argument for this bimoraic metrical structure is reinforced by evidences such as hypocoristic formation and secret language (Poser 1990, Ito, Kitagawa \& Mester 1996). From the analysis of default accentuation, we know that the use of bimoraic feet extends to accent assignment in Japanese, as in many other languages.

\subsection{Optimality Theory analysis for default accent pattern}

The constraints used for the analysis of the default accent are as follows:

(14) List of constraints involved in the default accent system

a. FT-BIN: Feet are binary under moraic analysis.

b. NONFINALITY: No foot is final in PrWd.

c. ALL-FT-R: Every foot stands at the right edge of the PrWd.

d. RHTYPE=T: Feet have initial prominence.

e. PARSE- $\mu$ : Moras are parsed by feet.

f. ALIGN-FT-L: The left edge of a foot coincides with the left edge of a syllable.

g. WSP: Heavy syllables have prominence. 
The following question then arises: What are the conflicting preferences hiding behind the accent patterns of Japanese? The first conflict that we can identify exists between NONFINALITY and ALL-FT-R.

(15) (jyá.mu).su > jya.(mú.su)

The harmony statement in (15) translates into a ranking argument for the above constraints:

\section{NONFINALITY 》ALL-FT-R}

Next, consider whether there is evidence to support quantity-sensitivity apart from a preference for NONFINALITY. Such evidence indeed exists, and it comes from two sources. First, it is more important for the final mora to be extrametrical than for the heavy syllable to be accented, as in the pair in (16). In the actual form, the final mora is extrametrical. In the suboptimal form, the heavy syllable at the end of PrWd has prominence, thus violating NONFINALITY.

(16) (jyú.ha).i > jyu.(há.i)

The harmonic relation in (16) translates into a ranking argument for the constraints, NONFINALITY and WSP:

\section{NONFINALITY 》WSP}

Next, consider the positional relation between the syllable and the foot. Although the antepenultimate rule in (2) seems to be enough description to specify the accent, it is in fact problematic in the analysis here because it involves two different prosodic elements the mora and syllable. Thus, to avoid this technical issue, we must assume that the constraint ALL-FT-R conflicts with another alignment constraint ALIGN-FT-L. As shown in the above examples, Japanese words have at most one accent. Thus, it is supposed that there is only one foot in a prosodic word of accented nouns. When we consider the position of this unique foot, it is necessary to align the left of the foot with the left of the syllable, in addition to the requirement for NONFINALITY.

$$
\text { (án).ho.e }>\text { a(ń.ho).e, } \quad \text { ban.(bán).jii }>\text { ban.ba(ń.ji)i }
$$

Thus, ALIGN-FT-L 》ALL-FT-R 
The ranking between NONFINALITY, ALIGN-FT-L and ALL-FT-R is supported by the tableau in (18) below:

(18) /banbanjii/

\begin{tabular}{|l||c:c|c|}
\hline \multicolumn{1}{|c|}{ /banbanjii/ } & NONFINALITY & ALIGN-FT-L & ALL-FT-R \\
\hline \hline a. ban.(bán).jii & & $*$ & $* *$ \\
\hline b. $\quad$ ban.ba(ń.ji)i & & $* !$ & \\
\hline c. $\quad$ ban.ban.(jiii) & $* !$ & & \\
\hline
\end{tabular}

As discussed above, both constraints - ALL-FT-R and WSP - are dominated by NONFINALITY. Then, how can we determine the ranking relation between them? As shown in (19), the syllable weight has nothing to do with the accent placement. Thus, ALL-FT-R 》 WSP.

(19) /mooriihoatya/

\begin{tabular}{|l||c|c|}
\hline \multicolumn{1}{|c||}{ /mooriihoatya/ } & ALL-FT-R & WSP \\
\hline \hline a. & $*$ & $*$ \\
\hline b. (moo).rii.(hó.a).tya & $* * * * !$ & \\
\hline c. moo.a.tya & $* * * !$ & \\
\hline
\end{tabular}

Because it is assumed that there is only one foot in a prosodic word of accented nouns in Japanese, we know that PARSE- $\mu$ is positioned lower than ALL-FT-R in the ranking, as illustrated in (20) below.

(20) /maaboodoohu/

\begin{tabular}{|l||c|c|}
\hline \multicolumn{1}{|c||}{ /maaboodoohu/ } & ALL-FT-R & PARSE- $\mu$ \\
\hline \hline a. maa.boo.(dóo).hu & $*$ & $* * * * *$ \\
\hline b. (maa).(boo).(doo).hu & $* * * * * * * * * !$ & $*$ \\
\hline
\end{tabular}

From the discussion above, we can deduce the interaction of metrical constraints in a default accent system. The ranking of the constraints is in (21):

(21) NONFINALITY, FT-BIN, RHTYPE=T, ALIGN-FT-L 》ALL-FT-R 》WSP, PARSE- $\mu$ 
NONFINALITY, FT-BIN, RHTYPE=T and ALIGN-FT-L are all undominated in the ranking, because the extrametricality, foot binarity, prosodic prominence as trochaic, and foot positioning under the coincidence requirement between foot and syllable boundaries are all inviolable in the Japanese accent system. The constraint ALL-FT-R is ranked lower than both NONFINALITY and ALIGN-FT-L, but is higher ranked than WSP and PARSE- $\mu$, which is illustrated in (19) and (20). The ranking relation between WSP and PARSE- $\mu$ is irrelevant for the discussion. The ranking in (21) is supported by the tableaux in (22), (23) and (24).

\section{(22) /jyuhai/}

\begin{tabular}{|c|c|c|c|c|}
\hline /jyuhai/ & NONFINALITY & FT-BIN & RHTYPE=T & ALL-FT-R \\
\hline a. (jyú.ha)i & & & & $*$ \\
\hline b. jyu.(hái) & $* !$ & & & \\
\hline c. (jyú).hai & & $* !$ & & $* *$ \\
\hline d. (jyu.há)i & & & $* !$ & $*$ \\
\hline
\end{tabular}

\section{(23) /syanhai/}

\begin{tabular}{|l||c:c:c|c|}
\hline /syanhai/ & NONFINALITY & RHTYPE=T & ALIGN-FT-L & ALL-FT-R \\
\hline \hline a. & & & & $* *$ \\
\hline b. syán).hai & & & $* !$ & $*$ \\
\hline c. syan.ha)i & & & & \\
\hline d. (syan).(hai) & $* !$ & & & $* *$ \\
\hline e. (syań).hai & & $* !$ & & \\
\hline
\end{tabular}

(24) /banbanjii/

\begin{tabular}{|l||c:c|c|c|}
\hline /banbanjii/ & NONFINALITY & ALIGN-FT-L & ALL-FT-R & PARSE- $\mu$ \\
\hline \hline a. ban.(bán).jii & & $*$ & $* *$ & $* * * *$ \\
\hline b. ban.ba(ń.ji)i & & $* !$ & $*$ & $* * * *$ \\
\hline c. ban.ban.(jii) & $* !$ & & & $* * * *$ \\
\hline d. (ban).(ban).(jii) & & & $* * * * * !$ & \\
\hline
\end{tabular}

\subsection{Optimality Theory analysis for pre-antepenultimate patterns}

As discussed above, the default accent placement (i.e., antepenultimate rule) can be identified from the constraint ranking in (21). However, some loanwords cannot be accounted for under this analysis, such as loanwords with HLH\# and LLH\# structures. Based on an 
analysis of foreign place names used in Japanese, Kubozono (1996a) posits that most loanwords with HLH\# and LLH\# structures tend to be accented on the antepenultimate syllable rather than on the penultimate light syllable; for example, /á.ma.zon/ "Amazon," /ré.ba.non/ "Lebanon," /báa.ku.ree/ "Berkeley." These new patterns (i.e., pre-antepenultimate patterns) are present in a number of loanwords, and in adapted forms from Chinese as well. Regarding these accent patterns, Kubozono mentions that there are a number of words that fluctuate between the two accent patterns as exemplified in (8) and that this accent variation is related to the speaker's age to a certain extent, with young speakers generally permitting the pre-antepenultimate patterns more often than senior speakers.

This kind of age-related variation suggests that the accent changes in (26) have been in progress in the Tokyo Japanese dialect.
a. LĹH\# $\rightarrow$ ĹLH\#
b. HĹH\# $\rightarrow$ HLH\#

To explain this patterns, the adjustment for OT analysis discussed above would be required. I propose that the extrametricality for the final mora in the default accent pattern changes to the extrametricality for the final syllable. Consider the data provided in (26).

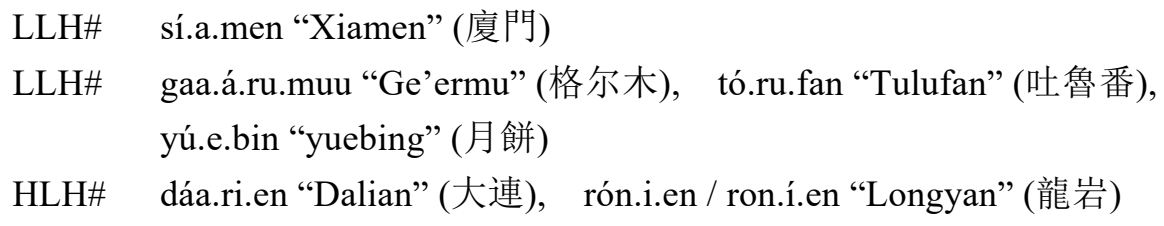

In the examples in (26), the antepenultimate syllable rather than the penultimate syllable is accented. As for /ron.i.en/ "Longyan" in HLH\# pattern, two variation are observed. However, one informant claims that it was difficult for him to identify the accent position (i.e., the antepenultimate or penultimate syllable). Therefore, I assume that as for the accent variations of words that have LLH\# or HLH\# combinations in the word-final position, the accent changes in (26) are now almost complete, with the new patterns overwhelming the old ones. In this new variation, NONFINALITY-SYL instead of NONFINALITY- $\mu$ is undominated in the constraint ranking. Thus, it is optimal for the adapted form /daa.li.en/ "Dalian" is accented on its antepenultimate syllable, as shown in (27). 


\section{(27) /daalien/}

\begin{tabular}{|l||c|c|}
\hline /daalien/ & NONFINALITY-SYL & ALL-FT-R \\
\hline \hline a. $*$ (dáa).li.en & & $* * *$ \\
\hline b. daa.(lí.e)n & $* !$ & $*$ \\
\hline c. daa.li.(én) & $* !$ & \\
\hline
\end{tabular}

\subsection{Optimality Theory analysis for unaccented patterns}

Lastly, we need to consider the unaccented patterns, which are observed in some words such as /urumuti/ and /anhoe/. Here, I present three possible solutions under the OT framework.

(i) No foot formation in the metrical structure: Assuming that no foot is formed in the metrical structure, the problem seems to be solved because the undominated constraints for no foot formation can vacuously satisfy other metrical constraints. However, this strategy would result in a technical problem. This problem is related to the prosody-morphology interface constraint $\mathrm{LX} \approx \mathrm{PR}$, which must be undominated for the PrWd to contain at least one foot.

(ii) Formation of unbounded foot: We need to postulate a constraint, by which unbounded is formed and no accent is put in such foot. If the constraint 'UNBOUNDED-FT' is undominated in the ranking, the footing problem of the unaccented patterns would be solved.

(iii) Two feet formation: In some studies on accents of the four-mora nouns, it is analyzed as comprising two feet. Shinohara (2004) proposes that a relation between the two-foot structure is a key point for its unaccentedness, and that the presence of only one foot might be a condition for the accent. However, it seems that the assumption that the two-foot structure is formed for LLLL\# or HLL\# only is not so strong.

\section{Conclusion}

From the above discussions, we find that there are some similarities between loanwords from English and adapted forms from Mandarin Chinese in terms of accentuation. First, both types of loanwords follow the antepenultimate rule defined in (2); thus, their accent system can be explained by the constraint ranking in (21): NONFINALITY, FT-BIN, RHTYPE=T, ALIGN-FT-L 》ALL-FT-R 》WSP, PARSE- $\mu$. Second, as for the words that have LLH\# 
or HLH\# structure at the end, both follow the pre-antepenultimate pattern. Thus, NONFINALITY-SYL (i.e., the final syllable is extrametrical) is required for analysis under the OT framework. Third, unaccented patterns are observed both in loanwords from English and in adapted forms from Chinese when four-mora words consist of LLLL or HLL.

However, there are still some differences between them. In loanwords from English, for instance, LH bisyllables generally follow the antepenultimate pattern, but they take an accent on the final heavy syllable if the initial light syllable contains an epenthetic vowel, as shown in Section 2. This accent displacement is attributed to the combination of two factors: no accent on epenthetic vowels and the WSP. However, this kind of accent displacement is not observed in adapted forms from Mandarin Chinese. It can be assumed that this difference drives from the fact that we normally cannot judge if vowel epenthesis is involved or not in Chinese words. As a result, we find that the WSP does not play a role in the accent system of words from Chinese.

Lastly, the accentuation of words from Mandarin Chinese is not related to the tonal system. In the study on Japanese adaptation (Shinohara 2004), it was found that the accentuation of adapted forms falls into two categories: (i) the accent is carried over from the accent of the source word, or (ii) no accent is carried over from the source words and the accent is assigned by default. Data provided in Section 3 indicate that the accentuation of adapted forms from Mandarin Chinese belongs to the latter category. 


\section{References}

Akegi, S. (2014) Chuugoku Chimei Katakana Hyooki-no Kenkyuu - Kyookasyo, Chizuchoo, sosite Kokugo Shingikai (Study of Katakana Notation of Place Name in China: Textbook, Atlas, and the National Language Council), Toho Shoten, Tokyo.

Haraguchi, S. (1999) "Accent" in Tsujimura, N. (eds), The handbook of Japanese Linguistics, Blackwell, Oxford, pp. 1-29.

Itô, Junko and Armin Mester (1995) "Japanese Phonology" in Goldsmith, John A. (eds), The Handbook of Phonological Theory, Blackwell, pp. 817-838.

Itô, Junko, Yoshihisa Kitagawa, and Armin Mester (1996) "Prosodic Faithfulness and Correspondence:

Evidence from a Japanese Argot," Journal of East Asian Linguistics 5, pp. 217-294.

Kubozono, H. (1999a) Nihongo no Onsei (The Sound System of Japanese), Iwanami Shoten, Tokyo.

Kubozono, H. (1999b) "Mora and Syllable" in Tsujimura, N. (eds), The Handbook of Japanese Linguistics, Blackwell, Oxford, pp. 31-61.

Kubozono, H. (2001) "Epenthetic vowels and accent in Japanese: facts and paradoxes" in Van de Weijer, J. and T. Nishihara (eds), Issues in Japanese Phonology and Morphology, Mouton de Gruyter, Berlin, New York, pp. 113-142.

Kubozono, H. (2006) "Where does loanword prosody come from? A case study of Japanese loanword accent," Lingua 16, pp. 1140-1170.

McCawley, J.D. (1968) The Phonological Component of a Grammar of Japanese, The Hague, Mouton.

Ogawa, S. (2004) "Sino-Japanese word accent and syllable structure," Phonological Studies 7, pp. 41-48.

Poser, William (1990) “Evidence for Foot Structure in Japanese,” Language, Vol 66, No. 1, pp. 78-105.

Prince, A. \& P. Smolensky (2004) Optimality Theory: Constraint interaction in generative grammar, Blackwell.

Shinohara, S. (2004) "Emergence of universal grammar in foreign word adaptations" in Kager, R., J. Pater, and W. Zonneveld (eds), Constraints in Phonological Acquisition, Cambridge University Press, Cambridge, pp. 292-320.

Tominaga, N. (2011) Chuugoku Ryoori Syoo-Jiten (Mini Dictionary of Chinese Food), Shibata Shoten. 